\title{
In the days of the comet
}

\author{
Dispatch 135 from the Oort Cloud Survey.
}

John M. Ford

$\Omega^{\mathrm{i}}$ amfield is dead, and this ship is very quiet now. I have tried to be hopeful in the recent dispatches: we were, Camfield certainly was. Prions are not supand they have. Which is part of the reason Camfield was out here in the first place.

He was a teller of jokes and he played the guitar very well - these are valuable things when you are doomed to spend years aboard a cantankerous old ship. Several instalments ago, I described the lab accident that infected Camfield, and I have received numerous messages calling the events absurd. This is true. In addition to myself, the organic Petrovna and the Neumann Thucydides saw the incident, and we all laughed until we realized Camfield was hurt. Petrovna, at least, can forget, although I do not think she will.

The prion has been decrypted and entered into the antigenic database, so no one should ever again die of Agent Op-1175s/CFD. posed to kill people any more, but they can,

Which is the story, but not its point.

At the cusp of this millennium we discovered that it was not hard to manufacture prions, and not that hard to custom-twist them. It took longer for our twists to be meaningful, but now organic humanity can don an armour of proteins for defence against a hostile Universe. Rather like viruses. Draw your own conclusions.

If one could find the right message, a prion would make a wonderful interstellar, even intergalactic, postal card: immune to temperature, pressure, radiation and time. The ideal pony for the express would be a comet, packed with messenger proteins, flung into a hyperbolic orbit, to seed any worlds at the far end with its cargo.

One could write one's name in the evolving life of a planet. At exactly the right moment, one might even begin the process, dropping a bouillon cube into the primordial soup.

Assuming that no one at the other end is quite as evolved, and quite as dependent on delicate higher neural functions, as we are.

So here we are, myself, 29 (down from 30)

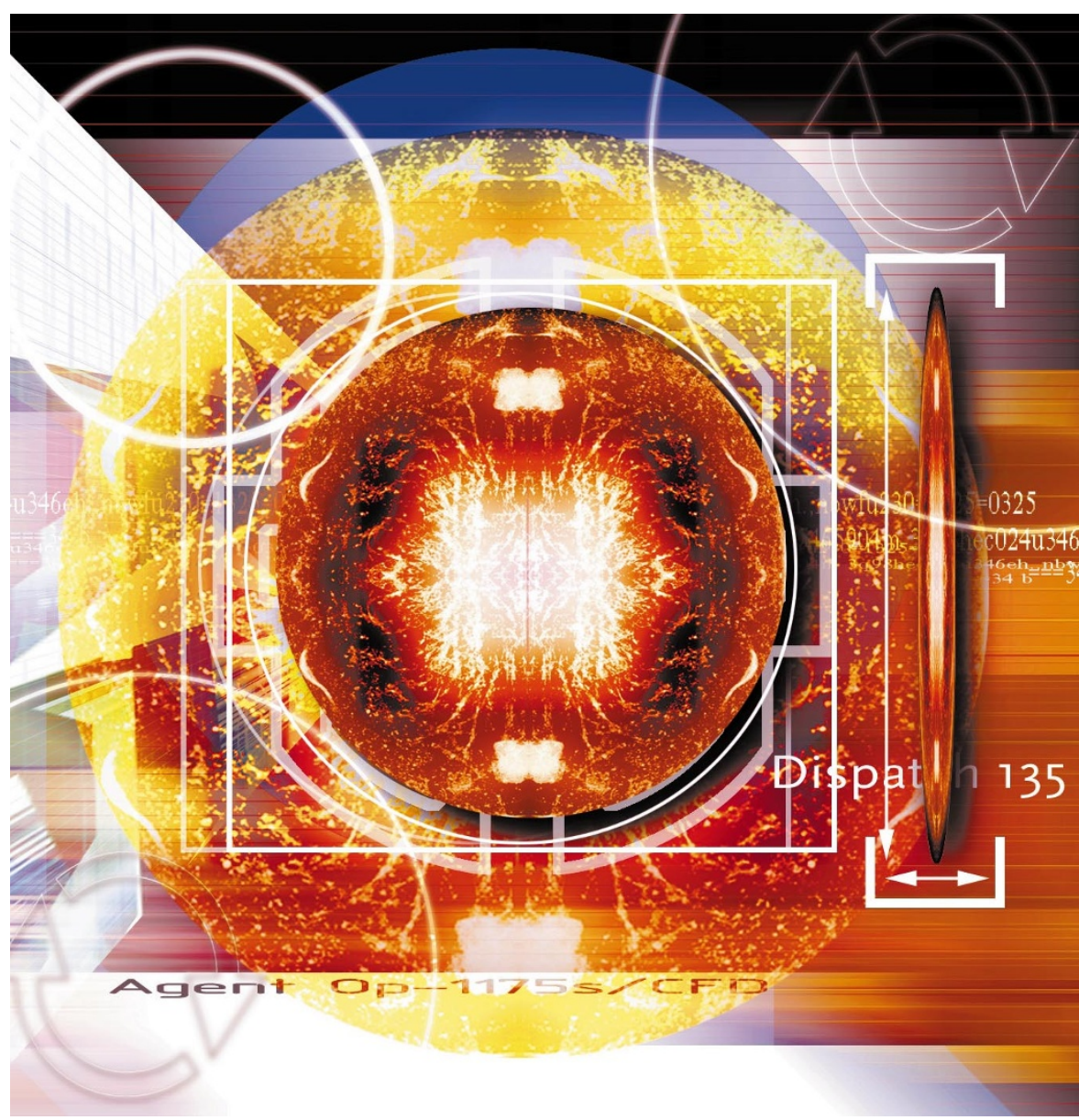

organic crew, and eight Neumänner, combing the comets of the Oort for prions. We have found a lot of prions, and there are a lot of comets left. You've got mail, as we said when I was organic.

Maybe. Or maybe one of the 48 published theories of spontaneous prion formation in comets is correct. It is the Neumänner who are most insistent on deliberate seeding. Perhaps it comforts them to think that, just as we built them, somebody built us. How human of them - but, as their namesake said, adequately describe any activity, and a machine can perform it.

In Camfield's last hours he was afire with fever, his whole body trembling, but there was a clarity in his speech that was at once heartbreaking and terrifying. Fischer, Chiang, and the Neumann Hypatia were tending him. Abruptly he calmed, fixed Chiang (and me, unavoidably) with a direct stare, and said, "I see the Martians now! They are flat, and they roll!" He shivered then, and I heard his heart stop.

The exclamation points are not added for drama. He was excited by what he saw, transported by whatever the alien messenger in his brain was revealing to him. Camfield was born on the Moon, not Mars, so we cannot explain away the vision as Heimsucht.

We cannot, of course, positively explain it at all. But we must examine the possibility that, eons ago, Op-1175s/CFD fell on Mars and began life there, which was later carried to Earth by a planetary blunt trauma.

Thucydides carefully wrapped and sealed Camfield's remains for storage until we return to the Moon, eight years from now. When he was done, Sid paused for two full minutes (exactly - we are like that), just looking at the bundle.

This kind of behaviour is by no means strange in a Neumann (one can adequately describe a thoughtful pause) but I asked Sid what he was thinking. He waited fourteen seconds longer - which was purely theatrical of him - and said, "I will miss Camfield. He was always interesting to be with, even when nothing was said. And has he not left us with a fine and difficult question?"

Camfield gave many gifts to his shipmates and his ship. The question - and it is fine he gave to all of us.

Autonomous Exploration Vessel John M. Ford was one of the first private citizens to undergo cortical shift, first to a netlinked mainframe, passing through a series of mobile installations to an AEV hull. In addition to his fiction (such as The Last Hot Time, to be published by Tor books) he is at work on The League of Steersmen, a history of the AEVs. 